\title{
MATERNAL BEHAVIORS OF SAANEN X HAIR GOAT CROSSES AT PARTUM AND EARLY POSTPARTUM DOE-KID RELATIONSHIPS
}

\author{
KAȘIKÇI, D. \\ Department of Animal Science, Faculty of Agricultural Sciences and Technologies, Isparta \\ Applied Sciences University, Isparta, Turkey \\ (e-mail:duyguince@sdu.edu.tr)
}

(Received $31^{\text {st }}$ Jul 2018; accepted $10^{\text {th }}$ Oct 2018)

\begin{abstract}
The purpose of this study was to describe maternal behavior of Saanen x Hair Goat crosses during and shortly after parturition and to determine the effect of some factors on doe-kid relationship. Parturition length, drying the kid by licking characteristics, time taken for placenta expulsion were taken as partum and postpartum behavior characteristics. Parturition length, time taken to lick, licking duration and time taken for placenta expulsion were found to be 129.8, 2.4, 21.35, $222.7 \mathrm{~min}$, respectively. Behavior traits belonging to kids were first attempt to stand up, time taken to stand up, first attempt to suckle and time taken to suckle, which were 5.7, 28.9, 38.8, 67.5 min, respectively. There was a positive correlation between time taken for placenta expulsion and licking. There was a significant correlation between first attempt to suckle and other traits $(\mathrm{P}<0.05)$.
\end{abstract}

Keywords: goat, Saanen $x$ Hair crosses, parturition behavior, maternal behavior

\section{Introduction}

Behavior is defined as the changes happening to the whole or some parts of the body of animals due to intrinsic or extrinsic factors (Unal and Akcapinar, 1994). Behavior makes animals adapt to internal changes of their body or the environment surrounding it. Most animals have behavior traits to try to benefit from their surroundings. Thus with trial and error behavior they adapt to their environment. When the animal does not have a previous experience, all behavior traits have a basic stimulant establishing the behavior. Understanding the basic stimulants peculiar to species is the fundamental part to understand animal's behavior and to control it (Demiroren, 2002). Before the animals were domesticated, humankind easily hunted wild animals by observing their behaviors. Later on humans either intentionally or unintentionally used animal behaviors especially social behaviors as selection criteria (Shackleton and Shank, 1984). At the root of some behaviors there are both instinct and experience. For example teat seeking behavior is instinctive however finding teats is by trial and error (Taylor and Field, 2001).

It is essential to test both maternal traits and care, and both offspring traits and development, as well as environmental factors, against offspring survival to disentangle the direct and indirect determinants of juvenile survival, a fundamental component of population dynamics (Gaillard et al., 1998). In addition, maternal efforts to maintain proximity with her young can directly enhance offspring survival by reducing predation risk (Grovenburg et al., 2012).

Goats have a keen sense of smell and good hearing. With the help of these senses they are able to find their kids within the group, select the grasses on pasture, distinguish the voices and establish mother-kid bond (Mackenzie, 1993). The most important behavior displayed after the birth is maternal behavior. Several factors such 
as age, parity, kid's feeding, breed, birth type, kid's stimuli (temperature, suckling, and movement) affect maternal behavior (Unal and Akcapinar, 1994).

Damron (2003) stated that maternal behavior is a complex relation that emerges after the birth, establishes bond between dam and kid, increases welfare and survival rate of the kid and increases lifelong yield of the kid.

Knowing kids behavior is very helpful as post-partum activities of kid such as, standing up and suckling, are very important for survival. When the mother lacks maternal behavior this may result in the low survival rate of the kid, death loss in first week due to undernutrition. Criteria that contribute to postnatal vitality that subjectively evaluate vitality of the kids are attempt to stand up and suckling behavior (Werning, 1993; Herpin et al., 1997; Cloete and Scholtz., 1998; Wollny, 2000; Leenhouvers et al., 2001).

The development of the connection between the mother and the new born kid was initially established at the time of birth through scent, and therefore the active licking is essentially important (Dwyer and Lawrence, 1998). Purpose of this study is to define and obtain data on maternal behaviors of Saanen X Hair Goat crosses at partum and early postpartum doe- kid relationships.

\section{Materials and methods}

Research was conducted in Small Ruminant Research farm at Suleyman Demirel University Applied Agricultural Research Center. Material of the study consisted of 22 female Saanen goats and their 36 kids. During the study goats were grazed on shrub and wheat stubble field. Goats received supplemental feed prior to parturition or when the grazing was insufficient.

Considering the insemination time and behavior, the goats that were going through labor were observed until birth took place. The goats approaching labor were transferred to a different paddock where their partum behavior were observed by 5 cameras recording from different angles. Behavior of kids were observed during parturition and maternal behavior of goats were recorded. Birth weight of kids were recorded right after kids were dried. When recording the behaviors, digital watch with a sensitivity of seconds was used and times were recorded.

Maternal behavior parameters recorded during the study were parturition length, licking properties (time taken to lick, licking duration) and placenta expulsion time. Kids behavior parameters recorded during the study were time taken to first attempt to stand up, time taken to first attempt to suckle and suckling duration.

During the study, goats that are going to give birth within two days were separated and housed in birth paddocks. Goats giving birth were observed for $24 \mathrm{~h}$. Definition of parturition and maternal behavior is presented below:

Parturition length (min): Time between first contraction and birth,

Time taken to lick (min): Time between parturition and mother's first lick, Licking duration (min): Time between first and last lick (Dwyer et al., 2000), Placenta expulsion time: Time between birth and expulsion of placenta,

Kid's first attempt to stand up (min): Time between birth and first attempt to stand up.

\section{Results and discussion}

Maternal properties such as parturition length, time taken to lick, licking duration, placenta expulsion time, and kids behavior parameters such as time taken to first 
attempt to stand up, time taken to first attempt to suckle and suckling duration are examined under two different subject. Descriptive data on parturition length, time taken to lick, licking duration, placenta expulsion time are provided in Table 1. When the data is examined it can be inferred that maternal behavior has a wide range.

Table 1. Descriptive data on maternal behavior

\begin{tabular}{c|c|c|c}
\hline Properties & Mean & Minimum & Maximum \\
\hline Parturition length (min) & 129.8 & 1 & 442 \\
Time taken to lick (min) & 2.4 & 0 & 27 \\
Licking duration (min) & 21.35 & 16 & 238 \\
Placenta expulsion time (min) & 222.7 & 33 & 488 \\
\hline
\end{tabular}

\section{Parturition length}

Of the maternal behavior, the most extensively examined property by researchers is parturition length and is defined as the time taken between first contraction and birth. Results showed that mothers giving birth at age of two had parturition length of $150 \mathrm{~min}$ and this was longer than older goats. As it can be seen in Table 1, the shortest parturition length was observed in 4-year-old goats $(90 \mathrm{~min})$ followed by 5 - and 6-yearold goats $(135,144 \mathrm{~min})$. Konyali et al. (2004) reported that in Turkish Saanen goats birth was given in $25 \mathrm{~min}$ after the labor started. However, in a research conducted on Gökçeada, Maltiz and Turkish Saanen goats, Tölü et al. (2013) found that parturition length ranged between 5.6 and 8.9 min and reported that the reason for this discrepancy was the definition and evaluation of parturition length in different studies. Tambajong (2002) found that birth was given in 131.8 min after the first labor started and in twin births second kid was born 22.3 min after the first kid was born. Parturition length is affected by birth type. Some researchers evaluating the parturition length reported that in twin births first kid was born between 14.5 and 131.8 min and second kid was born between 6 and 22 min after the first kid was born (Sambraus and Wittman, 1989; Ramirez et al., 1995; Das and Tomer, 1997; Tambajong, 2002). Parturition length for single and twin births was found 97.06 and $161.87 \mathrm{~min}$, respectively, and it was observed that birth type had a significant effect on parturition length $(\mathrm{P}<0.01)$. As litter size increased parturition length increased. Parturition length was not affected by dam's age. These results agree with Sambraus and Wittman, 1989; Ramirez et al., 1995; Das and Tomer, 1997; Tambajong, 2002 who worked on different breeds. When the range in descriptive data of maternal behavior is considered, it is likely possible that there was a difficulty in finding the correct definition for labor.

\section{Drying properties}

This parameter was examined to define the first orientation or interest in small ruminants after parturition. After the birth, as a first act, small ruminants look for their kids or feed, water or similar objects. Mother commences to lick the kid soon after the birth. Time taken to lick (TTL) is defined as the time between birth and first licking action. Licking duration (LD) is the time taken between first and last licking. Acceptance of kid by mother and time taken to lick vary depending on the mother's age. As mother gets older acceptance of kid by mother and time taken to lick shorten (3.46, $2.17,1.81$ and $2.11 \mathrm{~min}$, for $2,4,5$ and 6 year ages, respectively). Average duration for 
TTL was $21.35 \mathrm{~min}$. The shortest TTL was observed in 5-year-old mothers whereas longest TTL was observed in 2-year-old mothers. Mother's age had no effect on searching for kid $(\mathrm{P}>0.05)$. Pushing the kids by head and front limbs and licking of kids to have them stand up are important to stimulate the kids to suckle (Konyali et al., 2006). Yilmaz et al. (2012) reported that TTL varied between 13.2 and $42.2 \mathrm{~s}$ and mother first starts licking from head. In a research on Toggenburg and Saanen goats, Lickliter (1985) reported that TTL was between 60 and $90 \mathrm{~s}$.

\section{Placenta expulsion time}

As it is observed in Table 2, dam's age and birth type had no effect on placenta expulsion time $(\mathrm{P}>0.05)$. Average time for placenta expulsion time was $222.69 \mathrm{~min}$. Even though it was not significant, placenta expulsion time increased as age of dam increased. Konyali et al. (2006) reported that placenta expulsion took place in one to two hours. In another research conducted on Norduz goats Yilmaz (2012) reported that placenta expulsion time was $120.74 \mathrm{~min}$. In a study conducted on goats, Konyali et al. (2004) reported that dam's age had a significant effect on placenta expulsion time and placenta expulsion time decreased as dam's age increased (146 min for 2 years old goats, 115 min for 3 years or above).

Table 2. Means and standard errors for mother's age and the birth type (min)

\begin{tabular}{c|c|c|c|c}
\hline & $\begin{array}{c}\text { Parturition length } \\
(\mathbf{m i n})\end{array}$ & $\begin{array}{c}\text { Time taken to lick } \\
(\mathbf{m i n})\end{array}$ & $\begin{array}{c}\text { Licking } \\
\text { duration }(\mathbf{m i n})\end{array}$ & $\begin{array}{c}\text { Placenta expulsion } \\
\text { time (min) }\end{array}$ \\
\hline Mother's age & & & & \\
2 & $150.03 \pm 17.84$ & $3.46 \pm 60.10$ & $23.5 \pm 14.2$ & $189.09 \pm 23.49$ \\
4 & $90.14 \pm 22.18$ & $2.17 \pm 58.36$ & $24.0 \pm 13.3$ & $197.18 \pm 29.04$ \\
5 & $135.22 \pm 23.07$ & $1.81 \pm 20.42$ & $19,3 \pm 20.4$ & $237.88 \pm 30.19$ \\
6 & $144.35 \pm 27.47$ & $2.11 \pm 21.70$ & $18.6 \pm 17.5$ & $266.38 \pm 36.26$ \\
\hline Birth type & $* *$ & & $*$ & \\
Single & $97.06 \pm 20.33$ & $2.27 \pm 1.32$ & $18,09 \pm 11.8$ & $194.36 \pm 22.16$ \\
Twin & $161.87 \pm 17.48$ & $2.51 \pm 0.92$ & $24,61 \pm 16.9$ & $250.34 \pm 37.61$ \\
\hline Mean & $129.87 \pm 9.84$ & $2.38 \pm 0.60$ & $21,35 \pm 17.5$ & $222.69 \pm 30.19$ \\
\hline
\end{tabular}

$* \mathrm{p}<0.05, * * \mathrm{p}<0.01$

\section{Kids' behaviors}

Behaviors belonging to kids such as first attempt to stand up, time taken to stand up, first attempt to suckle, time taken to suckle are presented in Table 3.

Table 3. Descriptive data on kids' behavior

\begin{tabular}{c|c|c|c}
\hline Properties & Mean & Minimum & Maximum \\
\hline First attempt to stand up (min) & 5.7 & 1 & 96 \\
Time taken to stand up (min) & 28.9 & 4 & 160 \\
First attempt to suckle (min) & 38.8 & 1 & 211 \\
Time taken to suckle (min) & 67.5 & 8 & 201 \\
\hline
\end{tabular}




\section{First attempt to stand up and time taken to stand up}

Post partum activities of kids (standing up and suckling) are very important for the kids' survival. These traits are influenced by mothers' and kids' behaviors. First attempt to stand up and time taken to stand up are presented in Table 3. Mother's age had no effect on first attempt to stand up and time taken to stand up ( $\mathrm{P}>0.05$; Table 4). When the first attempt to stand up time is examined it is observed that as mother's age increased first attempt to stand up time increased. The only exception to this were 6 years old mothers that showed similar results with 2 years old mothers. Time taken to stand up followed the same trend as the first attempt to stand up and kids of two years old mothers stood up earlier than other mothers' kids. Sex of kid had no influence on time taken to stand up ( $\mathrm{P}>0.05)$. Similar results were reported by Cloete et al. (2002) who found that sex had no impact on time taken to stand up. Lickliter (1985) reported that most of the kids (62\%) stood up in 15 min after the birth. In a study conducted on Boer goats Tambajong (2002) reported that of the twins, first born twin stood up in $28 \mathrm{~min}$ whereas second born stood up in $36 \mathrm{~min}$. A study comparing time taken to stand up of Turkish Saanen kids with Gokceada and Maltase found that Saanen kids needed longer time $(20.9 \mathrm{~min})$ than Gokceada and Maltase kids $(\mathrm{P}<0.05)$. In addition to birth weight and APGAR score, mother's attention on kid has an effect on time taken to stand up (Dwyer, 2003; Savas, 2007). Konyali et al. (2006) reported that single born kids stood up in 23.5 min and of the twins, first born and second born stood up in 24.9 and 27.5 min, respectively. Reaserch showed that Gokceada and Maltase kids have shorter time taken to stand up. Time taken to stand up is affected by birth weight and lighter Gokceada kids stand up earlier than heavier Saanen kids. In this study it is interesting to observe that twins took less time than single born kids to stand up and this result contradicts with literature. However, obtained results with regards to time taken to stand up are in agreement with literature.

\section{Suckling behavior}

Survival of kids mostly depend on standing up and suckling in the shortest time possible. In this research kids born to 2, 4, 5 and 6 years old mothers needed 44.2, 50.3, 26.9 and $33.8 \mathrm{~min}$ for first attempt to suckle, respectively, and 66.5, 76.1, 57.7 and 69.6 min for time taken to suckle (Table 4). This showed that mother's age had influence on these behaviors. Kids born to 2 and 4 years old mothers tended to have longer time for first attempt to suckle, and kids born to 4 years old mothers tended to have longer time for time taken to suckle. In a study conducted on Toggenburg and Saanen goats Lickliter (1985) reported that time taken to suckle ranged between 14 and 185 min with average of 49 min. Birth type and sex had no effect on first attempt to suckle and time taken to suckle. Mean time for first attempt to suckle and time taken to suckle were 38.8 and 67.5 min, respectively.

\section{Phenotypic correlations among behavior traits}

Correlation analyses were performed to document relationship among traits. The results are reported in Table 5. As parturition length increased placenta expulsion, drying traits, time taken to stand up and first attempt to suckle time increased. These results are expected as these behavior traits are displayed after parturition. There was a positive correlation between placenta expulsion time and drying traits. There were important correlations among first attempt to suckle and other traits. As parturition length increased 
placenta expulsion time increases naturally. Increase in parturition length affects first attempt to stand up as mother spends more energy and is under stress. The same way, increase in placenta expulsion time affects drying traits, time taken to stand up and first attempt to suckle. Time taken to stand up also affects first attempt to suckle and time taken to suckle as they are correlated and dependent to each other.

Table 4. Mother's age, birth type and sex on kids' behavior

\begin{tabular}{c|c|c|c|c}
\hline & $\begin{array}{c}\text { First attempt to } \\
\text { stand up (min) }\end{array}$ & $\begin{array}{c}\text { Time taken to } \\
\text { stand up (min) }\end{array}$ & $\begin{array}{c}\text { First attempt to } \\
\text { suckle (min) }\end{array}$ & $\begin{array}{c}\text { Time taken to } \\
\text { suckle (min) }\end{array}$ \\
\hline Mother's age & & & & \\
2 & $4.5 \pm 4.0$ & $24.8 \pm 8.0$ & $44.2 \pm 8.0$ & $66.5 \pm 11.7$ \\
4 & $6.5 \pm 5.3$ & $30.3 \pm 8.3$ & $50.3 \pm 10.6$ & $76.1 \pm 9.8$ \\
5 & $6.7 \pm 5.6$ & $29.5 \pm 6.1$ & $26.9 \pm 11.3$ & $57.7 \pm 12.6$ \\
6 & $5.1 \pm 6.3$ & $31.2 \pm 9.1$ & $33.8 \pm 11.4$ & $69.6 \pm 13.5$ \\
\hline Birth type & & & & \\
Single & $6.7 \pm 14.3$ & $32.6 \pm 10.6$ & $44.7 \pm 12.3$ & $60.7 \pm 14.8$ \\
Twin & $3.4 \pm 7.0$ & $23.8 \pm 5.2$ & $32.4 \pm 7.5$ & $74.3 \pm 8.4$ \\
Sex & & & & \\
Male & $6.2 \pm 3.6$ & $29.3 \pm 5.7$ & $39.7 \pm 7.6$ & $70.0 \pm 8.9$ \\
Female & $4.0 \pm 3.1$ & $27.2 \pm 4.5$ & $37.5 \pm 6.1$ & $65.2 \pm 7.2$ \\
\hline Mean & $5.7 \pm 10.1$ & $28.29 \pm 3.93$ & $38.8 \pm 5.26$ & $67.50 \pm 5.21$ \\
\hline
\end{tabular}

Table 5. Phenotypic correlations among behavior traits

\begin{tabular}{c|c|c|c|c|c|c|c|c}
\hline & $\begin{array}{c}\text { Parturition } \\
\text { length }\end{array}$ & $\begin{array}{c}\text { Placenta } \\
\text { expulsion } \\
\text { time }\end{array}$ & $\begin{array}{c}\text { Time } \\
\text { taken to } \\
\text { lick }\end{array}$ & $\begin{array}{c}\text { Licking } \\
\text { duration }\end{array}$ & $\begin{array}{c}\text { First } \\
\text { attempt to } \\
\text { stand up }\end{array}$ & $\begin{array}{c}\text { Time } \\
\text { taken to } \\
\text { stand up }\end{array}$ & $\begin{array}{c}\text { First } \\
\text { attempt } \\
\text { to suckle }\end{array}$ & $\begin{array}{c}\text { Time } \\
\text { taken to } \\
\text { suckle }\end{array}$ \\
\hline $\begin{array}{c}\text { Parturition } \\
\text { length }\end{array}$ & 1.000 & $0.280^{*}$ & $0.448^{* *}$ & $0.243^{*}$ & 0.055 & $0.294^{* *}$ & $0.224^{*}$ & -0.002 \\
\hline $\begin{array}{c}\text { Placenta } \\
\text { expulsion } \\
\text { time }\end{array}$ & 1.000 & $0, .294^{* *}$ & $0.280^{* *}$ & 0.118 & $0.371^{* *}$ & $0.275^{*}$ & 0.142 \\
\hline $\begin{array}{c}\text { Time taken } \\
\text { to lick }\end{array}$ & & 1.000 & $0.237^{*}$ & $0.414^{* *}$ & $0.363^{* *}$ & $0.325^{* *}$ & -0.045 \\
\hline $\begin{array}{c}\text { Licking } \\
\text { duration }\end{array}$ & & & 1.000 & $0.387^{* *}$ & $0.250^{*}$ & $0.371^{* *}$ & -0.111 \\
\hline $\begin{array}{c}\text { First } \\
\text { attempt to } \\
\text { stand up }\end{array}$ & & & & 1.000 & $0.626^{* *}$ & 0.055 & $0.226 *$ \\
\hline $\begin{array}{c}\text { Time taken } \\
\text { to stand up }\end{array}$ & & & & & 1.000 & $0.807 * *$ & 0.215 \\
\hline $\begin{array}{c}\text { First } \\
\text { attempt to } \\
\text { suckle }\end{array}$ & & & & & & & 1.000 & 0.112 \\
\hline $\begin{array}{c}\text { Time taken } \\
\text { to suckle }\end{array}$ & & & & & & & & 1.000 \\
\hline$* 0,0.05, * * \mathrm{p}<0.01$ & & & & & & &
\end{tabular}




\section{Conclusions}

Post partum behavior of mother is linked to kid's survival. Knowing post partum behavior of mother and kids are important to reduce mortality rate in kids and to increase survival of kids. First contact between mother and kid starts with mother's lick. Licking action normally should start right after the birth. Thus breeders should pay attention to mothers' licking behavior and should control the environmental factors adversely affecting mother's behavior (hunger, cold, diseases). In addition breeders should pay attention to mothers having dystocia and should locate these mothers and kids in individual paddocks. This practice would benefit the kids as mother would give all attention to the kids. As a result, it can be inferred that behavior traits of mother and kids should be defined under different conditions. In this case problems related to mother and kid behavior can be controlled and some breeding techniques to increase productivity can be implemented.

Acknowledgements. This study was supported by the Suleyman Demirel University Scientific Research Project Coordination Unit. The author wish to thank Prof. Dr. Hayati Koknaroglu, Suleyman Demirel University, for reviewing the English manuscript.

\section{REFERENCES}

[1] Cloete, S. W. P., Scholtz, A. J. (1998): Lamb survival in relation to lambing and neonatal behaviour in medium wool merino lines divergently selected for multiple rearing ability. - Australian Journal of Experimental Agriculture. 38: 801-811.

[2] Cloete, S. W. P., Scholtz, A. J., Gilmour, A. R., Olivier, J. J. (2002): Genetic and environmental effects on lambing neonatal behaviour of Dormer and SA Mutton Merino lambs. - Livestock Production Science 78: 183-193.

[3] Damron, W. S. (2003): Introduction to Animal Science: Global, Biological, Social and Indrustry Perspectives Al, Second Edition. - Prentice Hall, Upper Saddle River, N.J.

[4] Das, N., Tomer, O. S. (1997): Time pattern on parturition sequences in Beetal goats and crosses: comparison between primiparous and multiparous does. - Small Ruminant Research 26: 157-161.

[5] Dwyer, C. M. and Lawrence, A. B. (1998): Variability in the in expression of maternal behaviour in primiparous sheep: effects of genotype and litter size. - Applied Animal Behaviour Science 58: 311-330.

[6] Dwyer, C. M., Lawrence, A. B., Bishop, S. C., Lewis, M. (2003): Ewe-lamb bonding behaviours at birth are affected by maternal undernutrition in pregnancy. - British Journal of Nutrition 89: 123-136.

[7] Demirören, E., Taşkın, T., Takma, Ç. (2002): The physiologic adaptation abilities of sheep and goats under excessive temperatures. - Ege University, Journal of Agriculture Faculty 39(2): 79-86.

[8] Gaillard, M. J., Anderson, R., Delorme, D., Linnell, J. D. C. (1998): Family effects on growth and survival of juvenile roe deer. - Ecology 78: 2878-2889.

[9] Grovenburg, T. W., Monteith, K. L., Klaver, R. W., Jenks, J. A. (2012): Predation evasion by white-tailed deer fawns. - Animal Behaviour 84: 59-65.

[10] Harvey, W. R. (1990): Instruction for Use of LSMLMM Least-Square and Maximum Likelihood General Purpose Program. - Ohio State Univ., Columbus.

[11] Herpin, P., Hulin, J. C., Fillajut, M., Gauthier, J., Le Dividich, J. (1997): L’hypoxie de Parturition Frequence et Incidence sur la Viabilite du porc nouveau-ne. - Journees Rech. Porcine en France 29: 56-66. 
[12] Konyalı, A., Daş, G. (2004): Oğlaklarda Doğumdan İlk Ayağa Kalmaya ve İlk Defa Emmeye kadar Geçen Süreye Etki Eden Faktörler. - 4. Ulusal Zootekni Bilim Kongresi. Poster Bildiriler. 1-3 Eylül 2004, Isparta, pp. 81-83.

[13] Konyalı, A., Tölü, C., Daş, G., Savaş, T. (2006): Der Einfluss von Geburt und neonatalem Verhalten auf das Wachstum bei Türkischen Saanenlämmern. Züchtungskunde 78: 230-240.

[14] Leenhouwers, J. I., de Almeida Ju nior, C. A., Knol, E. F., van der Lende, T. (2001): Progress of farrowing and early postnatal pig behavior in relation to genetic merit for pig survival. - Journal of Animal Science 79: 1416-1422.

[15] Lickliter, R. E. (1985): Behaviour associated with parturition in the domestic goat. Application of Animal Behaviour Science 13: 335-345.

[16] Mackenzie, D. (1993): Goat Husbandry, Chap.7 (Fifth edn.). - Faber and Faber, London.

[17] Ramirez, A., Quıles, A., Heıva, M. L., Sotillo, F. (1998): Behaviour of the MurcianoGranadina goat during the first hour after parturition. - Applied Animal Behaviour Science 56: 223-230.

[18] Sambraus, H. H., Wittmann, M. (1989): Beobachtungen zu Geburtsablauf und Saugverhalten von Ziegen. - Tierärztliche Praxis 17: 359-365.

[19] Shackleton, D. M., Shank, C. C. (1984): A review of the social behavior of feral and wild sheep and goats. - Journal of Animal Science 58(2): 500-509.

[20] Tambajong, D. D. S. J. (2002): Geburt, Saugverhalten und Milchparameter bei Burenziegen. - Dissertation, Institut für Tierzucht und Haustiergenetik derGeorg-August Universität, Göttingen.

[21] Taylor, E. R., Field, T. G. (2001): Scientific Farm Animal Production (Seventh edn.). Prentice-Hall Inc., Upper Saddle River, New Jersey.

[22] Tölü, C., Hıdıroğlu, Ö., Savaş, T. (2013): Keçi Genotiplerinin Oğlağını Tanıma ve Emzirme Davranışları Bakımından Karşılaştırılması. - Çanakkale Onsekiz Mart Üniversitesi Ziraat Fakültesi Dergisi (Çanakkale Onsekiz Mart University Journal of Agriculture Faculty) 1(1): 73-77.

[23] Unal, N. and Akcapinar, H. (1994): Sheep Behavior. - Journal of Animal Research 4(2): 113-123.

[24] Werning, D. K. (1993): Untersuchungen zur Entwicklung von Lammern bei herkömmlicher und mutterloser Aufzucht unter besonderer Berücksichtigung des Immunstatus. - Faculty of Medicine Veterinary Freie Universitat, Dissertation., Berlin.

[25] Wollny, T. (2000): Mutterlose Aufzucht von Heidschnuckenlämmern unter besonderer Berücksichtigung der Anwendung eines Tränkeautomaten. - Tierärztliche Hochschule Hannover, Dissertation, Almanya.

[26] Yılmaz, A., Karaca, S., Kor, A., Bingöl, M. (2012): Determination of pre-parturition and post-parturition behaviors of Norduz Goats. - Kafkas University, Journal of Veterinery Medicine 18(2): 215-219. 